\title{
ДО ПИТАННЯ ПРО МІСЦЕ ГРИ В СТРУКТУРІ СОЦІАЛЬНОї ВЗАЄМОДІї
}

\author{
М.О. Чулошнікова
}

.. Беретти та вивчати тонкий пар
симуляції на тілі неіснуючої реально-
сті - як те едине, що залишилося в
нас від традиції та класпки.
Aндрій Bеліканов

Традиційно так склалося, що в межах кожного суспільства місія підсумовування та декларації умонастроїв спільноти покладається на митців, науковців, громадських діячів. Саме ця категорія людей покликана гостріше відчувати та активніше реагувати на будь-які відчутні або латентні зрушення у всій структурі соціальної дійсності та прогнозувати зворотній зв'язок. Залученість в таку діяльність виправдовуе означений статус цих індивідів та надае їм відчуття повноти самореалізації.

Що робити митцю після того, як було виголошено численні декларації про смерть мистецтва? Що має відчувати політик, почувши вердикт, що політика, як сфера його покликання - суцільно брехлива та наскрізь блюзнірська справа? Чи втримується в межах оптимістичного світогляду економіст, науковець, громадський діяч, коли зустрічається з тезою про те, що вся об'єктивна реальність просотана хибою, штучністю, лицемірством й, навіть перетнувши межу тисячоліття, так само буксує в постмодерновій безвиході? Чи можливо тепер займатися творчістю в будь-якій формі без ризику перетворити весь соціальний простір в суцільну «Гру в бісер» і самому не стати при цьому жертвою тотальної симуляції та нещирості?

Актуальні проблеми духовності:

зб. наук. праць / Ред.: Я.В. Шрамко

Вип. 11. - Кривий Ріг, 2010, 369-381 369

ISSN $2076-7382$ 
Об'ективна дійсність все частіше розчаровуе сучасну людину, викликає невдоволення та неприйняття, заперечення або протест, обурення або відчай. Парадоксальні правила суспільного життя породжують широкий спектр реакцій - від нестримного бажання терміново діяти, змінювати, перетворювати оточення, навіть в асоціальній чи руйнівній формах, до повного відсторонення і байдужості, занурення у себе, ігнорування об'ективної дійсності взагалі. Активність кожної людини в умовах соціального оточення завжди пов'язана 3 реакціями інших людей, опосередковано чи безпосередньо. Тому важко уявити таку форму активності людини, підгрунтям для здійснення якої не стають певні прогнози й очікування реакції оточення. Оцінка оточенням активності індивіда, в свою чергу, $є$ наслідком попередніх соціальних дій. Подібна «ланцюгова реакція» взаємопов'язаних соціальних актів дістала назву соціальної взаємодії, яка й слугує підгрунтям для соціальних відносин.

Соціальний універсум в свою чергу формується на грунті соціальних відносин і відтак набуває притаманних їм характеристик. Розмотавши цей причинний клубок в зворотному напрямку, ми зможемо знайти той елемент, за допомогою якого трансформовані соціальні взаємодії здійснюють негативний вплив на суспільну дійсність і змінюють характер їі сприйняття.

$$
\begin{gathered}
\text { Соціальний контакт - соціальна діл } \\
\text { - сочіальна взаемодія - } \\
\text { соціальні відносини - соціальні системи. }
\end{gathered}
$$

Припустимо, що стійкість та проблематичність суспільного негативізму викликана не стільки його нездоланністю чи недостатністю зусиль щодо його нейтралізації, скільки в недостатній дослідженості цих негативних явищ соціальної реальності. Детальний перегляд концепцій соціальної взаємодії, визначення місця і ролі гри в структурі соціальної взаємодії дозволить, на нашу думку, прояснити корені деяких негативних змін у соціальних відносинах та соціальних системах й, можливо, певним чином їх скорегувати. В коло нашої уваги також потрапляе процес соціалізації, адже повноправним членом суспільства людина стає саме у процесі соціальної взаємодії. Крім того, у вказаному контексті дослідження важливими $\boldsymbol{\epsilon}$ особливості процесу формування принципів, правил та норм, згідно з якими відбуваються процеси соціальної взаємодії.

Сучасні дослідження традиційно фіксують два рівня соціальної взаємодії: міжособова інтеракція (мікрорівень) та інституційна інтера- 
кція (макрорівень) [1]. Умовно кажучи, механізми формування, здійснення та актуалізації соціальної взаємодії на обох цих рівнях розрізняються в першу чергу за масштабами наслідків та впливу на соціальний універсум та людину, як його складову. Відповідний висновок можна зробити, здійснюючи порівняльно-узагальнюючу характеристику теорій виникнення соціальної взаємодії.

Низка теорій, що репрезентують наявний стан наукової думки стосовно предмету нашої уваги в межах означеної статті, представлена переважно західними авторами: Дж. Хомансом та Р. Парком (теорія соціального обміну), Дж. Мідом та Г.Блумером (теорія символічного інтеракціонізму), Г. Гарфінкелем (етнометодологія), Т. Парсонсом (теорія соціальної дії-I), Ю. Хабермасом (теорія соціальної дії-II) [1], Е. Гофманом (теорія драматичного підходу) [2]. Неабияку увагу дослідженню теорії соціальної взаємодії приділяв також П. Сорокін [7].

Зазначені дослідження не $є$ рівноосяжними за глибиною, детальністю, векторами спрямування дослідницької активності, проте можна виокремити спільні тези, що об'єднують вищеназвані теорії. Перш за все, звернемось до розгляду сутності соціальної взаемодії. Так, наприклад, всі дослідники зазначають, що основою виникнення соціальної взаємодії $€$ переважно певні дії або реалії, що мають взаємовиключний, суперечливий або конфліктний характер:

- соціальна нерівність в суспільстві та відповідне прагнення людини її подолати (Пітірім Сорокін) [7, с.68],

- складна система обмінів, зумовлених засобами врівноваження винагород та витрат (Дж.Хоманс) [1, с. 142],

- вчинки, засновані на комунікації, в якій людина реагуе не тільки на дії, але й на наміри інших людей; безперервний діалог, у процесі якого люди спостерігають, осмислюють наміри один одного та реагують на них (Дж. Мід) [1, с. 142],

- процес взаемообміну, що відбувається в так званих «зонах взаемопроникнення» (Т. Парсонс) [1, с. 143],

- стан конфлікту між тим, що інстинктивно подобається людині та абстрактними правилами, які прищеплюються, а також потреба подолання цього протиріччя в процесі стихійного спілкування в межах малих інтимних спільнот людей (Е. Гофман) [2, с. 191], 
- характер відносини в умовах рівності та нерівності людей, що перебувають на різних соціальних позиціях [4, с. 104],

- процес взаємодії індивідів, соціальних груп або спільнот одна на одну в ході реалізації їх інтересів (Н. Смелзер) [4, с. 106].

Варто зазначити, що майже в усіх переглянутих роботах, має місце ідея про кінцеву функцію, або призначення (результати, наслідки) соціальної взаємодії. Парсонс вважає соціальну систему продуктом та безпосереднім результатом процедури соціальної взаємодії індивідів, причому певна структура џих систем виникае не сама по собі, а через актуалізацію процесу соціальної взаємодії. На його думку, соціальна взаємодія - саме той елемент, шо надає соціальним системам в процесі свовї актуалізації певних «емерджентних властивостей» [1, с. 144]. Саме за соціальною взаємодією закріпляе функцію створення підвалин суспільної солідарності та приведення суспільства як системи до стану рівноваги Дж. Хоманс. В межах теорії символічного інтеракціонізму (Дж. Мід) та близької до неї етнометодології (Г. Гарфінкель) соціальна взаємодія наділяється функцією налагодження процесу ефективної комунікації між її суб'ектами, що надалі, по-перше, сприяе становленню та розвиткові самої особистості, а по-друге - формуванню соціальної системи, зміні в соціальній структурі суспільства, утворенню соціальних інститутів [4]. Функцією фіксації, передачі та збагачення культурного досвіду також наділяв соціальну взаємодію П. Сорокін $[7$, с. 70]. Зазначимо, що, виникаючи внаслідок різної спрямованості попередніх чинників, соціальна взаємодія наближається в своїх функціях до примирюючої, навіть креаційної місії.

Також не можна оминути той факт, що, сприяючи налагодженню ефективної комунікації між її суб'єктами, створенню підвалин суспільної солідарності, соціальна взаємодія впливає на процес становлення та самоідентифікації людини, реалізації її в якості Людини як такої, а також повноправного члена свого суспільства. Щодо з'ясування сутності та значення соціальної взаємодії в процесі соціально-філософського аналізу дослідники приходять до різних типологій: значущі та незначущі взаємодії (Дж.Мід), стратегічні, нормативні та драматургічні взаємодії (Ю. Хабермас) тощо. Визначені також види соціальної взаємодії:

- випадкова i навмисна, тимчасова i стійка, приватна i публічна, особистісна і речова, формальна і неформальна (М. Арчер, П. Штомпка, П. Бурдьє) [4]; 
- змагання, пристосування, соціальний конфлікт, асиміляція (Р. Парк) [4];

- відносини влади, переговорний процес, лідерство тощо (Дж. Хоманс) [1];

- довільне самовираження, яким люди подають інформацію про себе в загальнозначущих символах, та мимові.льне самовираження, яким вони видають себе (Й. Гоффман) [2].

Переважна кількість теорій визначае в якості рушійної сили, ядра соціальної взаємодії раціональне начало, що є іманентним Людині. В ході взаємодії люди прагнуть максимально рапіоналізувати свою поведінку з метою досягнення найбільшої економічної ефективності, тому для соціальних дій характерними е такі якості, як усвідомленість, раціональність та орієнтованість на інших, здійснюють взаємний обмін колективним досвідом, знаннями, поняттями, найвищим результатом якого е виникнення «культури» П. Сорокін [7, с. 72], намагаються віднайти ідеальне співвідношення між винагородами та витратами в процесі соціальної практики, прагнучи при цьому до вищого «бонуса» - соціального схвалення (Дж. Хоманс), «пересимволізує» комунікативну дію з метою інтеріорізації соціальної реальності (Й. Гофман, Г. Гарфінкель) $[1$, с. 122].

В межах різних наукових підходів дослідники вживають терміни «максимально раціоналізувати», «усвідомленість», «раціональність», «налаштованість на інших», «взаемний обмін», «прагнення соціального схвалення» та інші, що добре показують гармонізуючу природу та конструктивне «покликання» соціальної взаємодії. Отже, стосовно характеру суспільної взаємодії можна зробити висновок, що в процесі соціалізації реалізується основна функція соціальної взаємодії-гармонізація та конструювання відносин людини і суспільства.

У теоретичних дослідженнях соціальна взаємодія постае узагальненим поняттям, центральним для цілої низки соціологічних теорій. В основі цього поняття лежить уявлення про те, що соціальний діяч, індивід або суспільство завжди знаходяться в дійсному або уявному оточенні інших соціальних діячів та поводиться відповідно до цієї соціальної ситуації. При цьому автори кожної з теорій приходять майже до спільної думки стосовно виокремлення суб'єкта соціальної взаємодії та їі складових елементів.

3 точки зору теорії сопіального обміну суб'єктом сопіальної взаємодії $є$ людина, включена в процес обміну матеріальними та нематеріаль- 
ними цінностями. Прихильники теорї символічного інтеракціонізму суб'єктом соціальної взаємодії вважають людину, що намагається надати певного значення оточуючому світові через тлумачення дій іншої людини. Суб'єкт соціальної взаємодії за Мідом - це не якась незмінна структура, а безперервний процес [1, с. 142]. Для такої особистості принциповим $\epsilon$ не наявність здатності засвоювання готових соціальних норм, а проблема свідомого набуття нею здатності до самостійної оцінки поведінки та діяльності, набуття особистості. Особистість, безперечно, має соціальне походження та формуеться через діалог, який вчить вмінню розмовляти не тільки 3 іншими, але й 3 самим собою, вчить мислити, бо ж мислення, як відомо, і $€$ «внутрішній діалог». 3 точки зору інтеракціоністів, суб'єкт - це не $\boldsymbol{e}$ зовнішній стимул, а те, що людина виокремлюе з оточуючого світу, надаючи цьому певні значення. Саме такі індивіди, що мають «особистісне Я» та самі формують значення, складають основу суб'єкта соціальної взаємодії на макрорівні та самі виступають в якості такого (на макрорівні). При цьому будь-яка індивідуальна дія є не просто здійсненою, а суворо конституйованою та здійснюеться через оцінювання та тлумачення ситуації. Людина як особистість, перебуваючи в статусі суб'єкта соціальної взаємодії, набуває здатності інтеріорізувати соціальну дію, іншими словами - перетворювати зразки реакцій «інших» на ту чи іншу ситуацію у власні внутрішні мотиви до дії (role-talking). Індивід виступае в ролях інших людей перед самим собою, в кожній уявній ситуації наче б то розігруючи певну роль перед удаваною аудиторією, крок за кроком обмірковуючи, як будуть ті чи інші глядачі реагувати на його виконання, та в залежності від висновків відносно реакції, що очікується, вибирати майбутню лінію реальної поведінки. Таким чином, взаємодія проходить не стільки між індивідами як суб'єктами, цілісними неподільними особистостями, скільки між різними соціальними обличчями індивідів, начебто між персонажами, що їх зображує людина [6]. Існує думка, що теорія символічного інтеракціонізму дає більш реалістичне уявлення про механізми соціальної взаємодії, ніж теорія обміну. Проте, інтеракціонізм концентрує свою увагу на суб'єктивних уявленнях індивідів, що взаємодіють, кожен $з$ яких $є$ унікальним та неповторним. Саме тому на основі інтеракціонізму досить складно зробити узагальнення, застосовне до різноманітних життевих ситуацій.

Для Й. Гофмана людина постає художником, творцем образів. Людське життя - це виробництво вражень. Вміння керувати враженнями та контролювати їх означає вміння керувати іншими людьми (такий контроль здійснюеться за допомогою вербальних та невербальних за- 
собів спілкування, використовуеться у виробництві сучасної реклами, технологіях створення іміджу, PR) та стає засобом пізнання світу, а сам світ перетворюється на спектакль, де люди виконують свої «партії», створюючи той чи інший образ [2, с. 194].

П. Сорокін, в свою чергу, твердо впевнений, що окремо взятий індивід не може розглядатися в якості елементарної «соціальної клітини», або суб'єкта соціальної взаємодії: «. . . індивід як індивід - жодним чином не може вважатися мікрокосмом соціального макрокосма. Не може тому, що з індивіда ми можемо отримати тільки індивіда, і не можна отримати ні того, що називається «суспільством», ні того, що носить назву «суспільних явищ»... для останніх потрібно не один, а багато індивідів - принаймні, два» $[7$, с. 94$]$. Проте для того, щоб два чи більше індивідів складали дещо єдине ціле, що могло б розглядатися як елемент соціальної взаємодії, однієї тільки наявності суспільства або його елементу недостатньо. Необхідно також, щоб вони входили у взаємини між собою, тобто обмінювалися якимись діями та відповідними реакціям на ці дії [7, с. 95].

Саме активно творчий, свідомо перетворюючий та безперервно рухливий характер діяльності людини як суб'єкта соціальної взаємодії займає визначне місце у дослідженнях феномену соціальної взаємодії. Не можна уявити, яким чином такий суб'єкт може бути здатним до пасивної або асоціальної реакції на об'єктивний світ в разі його неспівпадіння з власними вимогами або очікуваннями. Навпаки, на тлі гармонізуючої ролі соціальної взаємодії вказані характеристики зумовлюють творчу, продуктивну реакцію суб'єкта. Нажаль, це не завжди так і часто можна спостерігати деструктивні, негативістські тенденції, що приводять до поглиблення розколу людини і суспільства. Зважаючи на конструктивний, гармонізуючий характер соціальної взаемодії, ми приходимо до припущення, що елемент, який провокуе такий стан речей, не може перебувати в структурі самої соціальної взаємодії або бути її іманентною характеристикого.

Спробуемо скласти узагальнене визначення поняття соціальної взаємодії на основі зазначених вищеназваними авторами характеристик. Соціальна взаємодія - це процес безпосередньої або опосередкованої взаємодії суб'єктів, обмін діями за участі двох або більшої кількості акторів. При цьому суб'єкти соціальної взаємодії здійснюють взаємний вплив. Така взаємодія є однією з основних життевих потреб Людини. В процесі соціальної взаємодії відбувається обмін інформацією, знаннями, досвідом, матеріальними та іншими цінностями; індивід (група) визначає свою позицію відносно інших, своє місце (статус) в соціаль- 
ній структурі, свої соціальні ролі. Роль, в свою чергу, приписуе індивіду певні зразки поведінки та робить взаємодію передбачуваною. Сама соціальна структура, соціальні відносини та соціальні інститути е результатом різних видів та форм соціальної взаємодії [1, с. 141].

3 іншого боку, соціальна взаємодія - особлива реальність, що виникає тільки в тих соціальних ситуаціях, де учасники фізично присутні й мають можливість безпосередньо реагувати на дії інших. Це одне 3 ключових понять суспільних теорій, тому що всі соціальні явища (соціальні відносини, процеси, зміни, соціальна структура, статуси, ролі тощо) виникають в результаті соціальної взаємодії, що складається 3 окремих, але взаємозв'язаних соціальних дій [3, с. 124].

Важливість соціальної взаємодії полягає в тому, џо лише завдяки ій людина може задовольнити переважну більшість своїх потреб, інтересів і цінностей. Суттєвою характеристикою соціальної взаємодії $€$ передбачуваність взаємних очікувань, або, інакше кажучи, взаєморозуміння між акторами. Якщо актори «говорять різними мовами» та переслідують взаємовиключні інтереси, то результати такої взаємодії навряд чи будуть позитивними $[4$, с. 125$]$.

Механізм соціальної взаємодії включає:

- індивідів (на мікрорівні) та соціальні групи (на макрорівні), що здійснюють ті або інші дії;

- зміни в соціальній спільноті або суспільстві взагалі, викликані цими діями;

- вплив цих змін на інших індивідів, що складають соціальну спільноту, i, врешті-решт, зворотну реакцію індивідів.

Також соціальна взаемодія постае як постійний обмін перевагами між людьми, а обмінні оборутки є елементарними актами суспільного життя, в результаті яких відбувається безперервний процес виробництва в соціумі особистісної самосвідомості-завдяки взаєминам 3 іншими людьми в межах соціальної взаємодії. Як відомо, особливості побудови будь-якої складної системи, яким би не був характер її походження, залежать не тільки від того, які елементи входять до їі складу, але й від того, яким чином вони поєднані між собою, як пов'язані, який вплив здійснюють одне на одного. По суті, саме характер зв'язку між елементами задае цілісність системи і зумовлюе виникнення емерджентних властивостей, які $\boldsymbol{\epsilon}$ характерною властивістю системи як єдиного цілого. Це справедливо для будь-яких систем, як відносно 
простих, елементарних, так і для максимально складних з усіх відомих нам систем - соціальних [4, с. 108].

Проведений нами огляд теорій соціальної взаємодії дозволяє підтвердити тезу, що соціальна взаємодія безперечно є важливою ланкою в складному процесі утворення соціальних відносин, і таким чином, опосередковано утворюе підвалини сприйняття людиною об'єктивного світу. 3 огляду на вищезазначене, можемо зробити висновок: соціальна взаємодія не може бути хибною, невірною, уявною, деструктивною чи схильною до саморуйнування та сама по собі не може провокувати у людини невдоволення або інші негативні почуття щодо суспільної дійсності.

Людина як суб'єкт соціальної взаємодії, також не має означених властивостей, більш того, вона, скоріш має прямо протилежні якості наполегливість, активність, небайдужість, раціональний підхід до визначення характеру дії, свідомість та відповідальність в процесі інтеріорізації об'єктивної дійсності та реалізації себе в цьому світі. Отже, ми можемо вказати на інший феномен, гіпотетично означений в нашій роботі як об'єкт дослідження в якості такого, який спричиняе негативне сприйняття Людиною соціального універсуму. Цим феноменом є гра.

Семантично гра здавна розуміється як така, що заперечуе аб́о профануе будь-який елемент серйозності, що потрапляе в її сферу або сам «впускає» іï до себе: «небезпечна гра»-ризик, виклик стабільності та спокою; «гра слів»-каламбур, що має на увазі шахрайську підміну змісту слів; «гра в слова» - використання бундючних фраз заради приховування істини або через брак власних думок; «гра природи»відхилення від звичних фізичних норм, потворність; «гра долі»-неочікуваний, приголомшливий випадок; «гра випадку»-непередбачуваність; «гра уяви» - пуста фантазія, вигадка. В теорії ж ігор гра тлумачиться як «формалізований опис (модель)» вирішення конфліктної, проблемної ситуації.

Гра нейтральна за своєю сутністю, за визначенням Й. Хейзінги, гра знаходиться «поза категоріями Добра та Зла» $[8$, с.168] і саме тому ігноруе бінарність опозицій, бо «незнайома» 3 ними. На нашу думку, деструктивний вплив гри на будь-які об'екти, зумовлений не самою нею як такою і також не специфікою їі феномену. Деструктивізм гри проявляється саме в процесі неконтрольованого пї привнесення в соціальну взаємодію. Неадекватне за обсягом та за семантикою використання гри на всіх рівнях соціальної взаємодії породжуе деструктивні явища в сфері політики, економіки, освіти, науки, культури тощо. 
Таким чином недостатня дослідженість гри як соціального феномену створюе умови для неконтрольованого проникнення гри на всі рівні соціальної взаємодії й утвердження так званого лудологічного тоталітаризму.

Іноді гра оголошується інструментом здійснення соціальних транзакцій, засобом пересимволізації подразників, що сприймаються суб'єктом соціальної взаємодії та частково виконуе структуроутворюючу роль. Такий підхід можна зустріти в межах теорії Й. Гоффмана, частково - Дж. Хоманса та Р. Парка. Та зазначимо, що в структурі соціальної взаємодії грі як такій місця немає. Місце гри, скоріш за все, «поряд»; для неї визначається суворо обмежена сфера існування, що постулюе саму гру в якості підготовчого етапу, передумови, полігону для випробувань, засобу компенсації перенапруження тощо. Іншими словами, в ланцюжку «соціальний контакт - соціальна дія соціальна взаемодія - соціальні відносини» гра мала б займати місце допрактичного або постпрактичного застосування. Зазначимо, що в добу постмодерного сприйняття світу людина вводить гру всередину сощіальної взаемодії, незважаючи на канони, правила та ігноруючи попередження. Тому всі ланки визначеного ланцюга, рівно як і сама соціальна взаємодія, так і соціальні відносини (як фактичний результат соціальної взаемодії) стають ігровими, а у подальшому - несерйозними, нестійкими, непродуктивними і не задовольняють саму людину.

Як умову виникнення соціальної взаємодії П. Сорокін виводить також наявність особливих передавачів, що передають подразнюючий вплив від одних учасників взаємодії до інших. Ця умова тісно пов'язана 3 тим, що інформація, яка передається в ході взаємодії, завжди зафіксована на певних матеріальних носіях. За такою точкою зору інформація взагалі не може поза матеріальних носіїв, бо ж навіть на найглибшому рівні інформація записана на тих самих матеріальних носіях - молекулах ДНК [7, с. 244]. В усіх випадках інформація передається та приймається за допомогою певних матеріальних носіїв, проте вони є нетривкими. Більшість носіїв інформації існують лише протягом періоду передачі-прийому, після чого зникають назавжди і їх необхідно кожен раз створговати наново. Порівнюючи способи та форми взаємодії людей та тварин Сорокін приходить до висновку, що найістотнішою відмінністю людської (а отже, соціальної) взаємодії від тваринного спілкування $\epsilon$ наявність так званої другої сигнальної системи. Сама ж друга сигнальна система, що е базою для виникнення абстрактно-образного мислення, може, на думку науковця, розвинутися лише в ході специфічно соціальної взаємодії. За відсутності будь- 
яких передавачів, що виступають носіями інформації, ні про яку взаємодію, як стверджуе Сорокін, не може бути й мови. Проте, при наявності передавачів, перешкодою для здійснення взаємодії не можуть бути ні простір, ні час [7, с. 251].

У такому контексті використання гри в допрактичній стадії актуалізації процесу соціальної взаємодії є цілком природнім. Дійсно, гра здатна прискорити, збагатити та оптимізувати процес опанування людиною другою сигнальною системою, стимулювати навчання спілкуванню в процесі розгортання свого універсуму, а також надалі дати можливість повторити, закріпити опановані навички в постпрактичному періоді.

В своїх роботах [7] П. Сорокін надає також перелік умов соціальної взаємодії, проте, на наш погляд, поза увагою вченого залишається така умова, як наявність спільної основи для контактів між соціальними суб'єктами. В найбільш узагальненому вигляді це означає, що більш-менш ефективна взаємодія може виникати лише тоді, коли обидві сторони розмовляють однією мовою. Йдеться не стільки про єдину лінгвістичну базу спілкування, скільки про приблизно однакове розуміння норм, правил, принципів, якими керуеться партнер по взаємодії. В іншому випадку взаємодія може або залишиться нездійсненою, або ж призвести до результату, що е прямо протилежним бажаному та очікуваному. Саме тут знову ж таки можна чітко визначити місце гри у соціальній взаємодії. У процесі вироблення навичок гра вчить розумітися 3 «різномовними» візаві на ігровому полі, тобто має місце допрактичне використання гри з метою удосконалення соціальної взаємодії.

Думка про те, що грає майже універсальним навчально-тренувальним засобом, яку висловлюють деякі дослідники, не витримуе критики в плані універсального статусу гри. Як зазначае психолог С. Френе, «Тільки в окремих випадках гра може готувати дитину до життя, навіть якщо вона формує якісь здібності або розвиває певні навички. Гра відволікае від реального життя; вона змушуе приймати за життя те, що $є$ всього лише їі тьмяною копією, і тому викривляє уявлення про основні питання буття» $[5$, c. 484$]$.

Не зовсім втішний прогноз розвитку такого стану речей стосовно абсолютизації ролі гри в соціальному універсумі взагалі та в житті людини зокрема, пропонуе американський письменник та футуролог Е. Тоффлер. Екстраполюючись від наявного стану речей, коли людина, невдоволена світом, або «ховається» в гру, або перетворює реальну дійсність на гру - (замість того, щоб напружуючись і долаючи себе та 
свої хиби та слабкості, докладати зусиль до змін џього Світу на краще) - він змальовує той час, коли людина, остаточно розбещена грою та знесилена опиратися її принадній небезпеці, буде втягнута в тотальний процес торгівлі та споживання. 3 ігровою легкістю людина, на думку Тоффлера, йтиме шляхом поверхневого, грайливого сприйняття всіх тих товарів та послуг, що їй буде запропоновано. Згідно 3 влучно прорахованою «психологами» від маркетингу (або маркетологами від філософії) мережею «товарів» буде формуватись також парадигма світобачення та спектр світовідчуття, що включатиме для «реалізації та споживання» окремі, штучні емоції та відчуття і психічні реакції. Буде запропоновано їх певну послідовність, організовану таким чином, що саме сполучення означених в переліку відчуттів буде надавати забарвленість, гармонійність або контрастність людському життю, якому не вистачає цих якостей. I такі «споживацькі кошики», на думку Тоффлера, стануть межею мрій пересічної людини майбутнього.

Таким чином, людина втрачає не тільки авторство в процесі творення власної індивідуальності, - вона припиняе процес самоідентифікації та самореалізації, закріпачується та втрачае набуті раніше пріоритети. Так само й світ, що постае перед нею, також не належить до сфери її творчості, а тому ввижається їй жахливим, небезпечним, блюзнірським та нікчемним, викликаючи його несприйняття чи відторгнення.

В попередніх роботах (див. [10, 11]) ми вже вказували на небезпеку бездумного використання гри в соціальній практиці людини, тому в цій статті ми спробували окреслити деякі кордони просування та сфери існування гри в соціальному універсумі, що дало можливість зробити деякі висновки. Процес соціалізації відводить грі суворо обмежену сферу існування, в межах якої використовуе гру як підготовчий етап, моделювання справжньої взаємодії - гра як допрактична діяльність. Соціальна практика використовує гру поза суспільною взаємодією, як форму відходу від реальних проблем, засіб зняття напруження тощо. В постпрактичному сегменті гра дозволяе переосмислити, підсумувати, систематизувати набутий досвід, надалі зафіксувати його (в правилах, умовах гри) та зберігати для передачі наступникам. Розглядаючи гру як допрактичну та постпрактичну діяльність, ми можемо констатувати її нейтральний характер, вільний від суспільних опозицій. Гра поза соціальною взаємодією являє собою творчу, конструктивну, позитивну діяльність. Привнесення гри в структуру соціальної взаємодії спотворює людське сприйняття суспільної дійсності і, навіть, об'єктивної реальності. Граничними випадками $\epsilon$ «лудологічний тоталітаризм» - 
перетворення певних видів соціальної взаемодії на гру, що породжуе цілий ряд негативних суспільних явищ. Нагальною потребою $е$ подальше дослідження взаємозв'язку гри та соціальної взаємодії, визначення впливу гри, можливих її обмежень та способів локалізації.

\section{1 Бібліографія}

[1] Городяненко В.Г. Соціологія. - К.: Академія, 2003.

[2] Гоффман $H$. Представление себя другим в повседневной жизни // Современная зарубежная социальная психология. - М.: Издательство Московского университета, 1984.- С. 188-196.

[3] Козырев Г.И. Социальное действие, взаимодействие, поведение и контроль // Социологические исследования. - 2005. - № 8 . C. 124-129.

[4] Комаров М.С. Введение в социологию.-М.: Просвещение, 2003.

[5] Репринцева E.A. Игра: мыслители прошлого и настоящего о её природе и педагогическом потенциале. - Москва-Воронеж, 2006.

[6] Ретюоских Л.Т. Философия игры. - М.: Вузовская книга, 2005.

[7] Сорокии П.А. Человек. Цивилизация. Общество. - М.: Просвещение, 2002.

[8] Хейзинга Й. Homo Ludens. - М.: Прогресc, 1992.

[9] Философская энциклопедия / Гл. ред. Ф.В.Константинов. - М.: Советская энциклопедия, 1970. - Т.5.

[10] Тулошнікова М.О. Феномен гри в контексті постмодерністської філософської парадигми // Актуальні проблеми духовності.Кривий Ріг: Видавничий Дім, 2006. - Вип. 7.- С. 445-452.

[11] Чулошнікова M.О. Поняття гри в структурі гуманітарного знання // Актуальні проблеми духовності. - Кривий Ріг: Видавничий Дім, 2007.- Вип 6. - С. 273-279.

Надійила до редакиї̈ 17 червня 2010 р. 